\section{Бедность и богатство: восприятие российских интернет-пользователей}

С.А. БАРКОВ, доктор социологических наук,

МГУ им. М.В. Ломоносова. E-mail: barkserg@live.ru

О.В. ГАВРИЛЕНКО, кандидат социологических наук,

МГУ им. М.В. Ломоносова. E-mail: ol.gavrilenko2014@yandex.ru

А.В. МАРКEЕВА, кандидат социологических наук,

МГУ им. М.В. Ломоносова. E-mail: anna_markeeva@mail.ru

Е.А. СВЕРДЛИКОВА, кандидат философских наук,

МГУ им. М.В. Ломоносова, Москва. E-mail: elena.sverdlikova@gmail.com

В статье на материалах проведенного контент-анализа сообщений в социальных медиа рассмотрены особенности отношения российских интернетпользователей к проблемам бедности и богатства. Общение в сети предполагает прагматическую направленность. Здесь не обсуждаются общие проблемь социально-экономического и социально-политического характера. Бедность и богатство воспринимаются сквозь призму потребительского поведения с целью поиска возможностей удовлетворения потребностей людей. В интернеткоммуникациях проявляется очевидная негативная оценка бедности, в то время как отношение к богатству и богатым, к социальной дифференциации общества представлено более нейтральными оценками. На первый план в обсуждениях выдвигается возможность поддерживать приемлемый уровень жизни в непростых экономических реалиях. Люди делятся рецептами выживания в условиях резкого сокращения доходов.

Ключевые слова: бедность, богатство, бедные, богатые, интернет-пользователи, социальные медиа, сетевые сообщества, инфляция, неравенство, потребление, зарплата, доход

Бедность как социально-экономическое явление в той или иной степени присуща любому обществу. Формы ее проявления и масштабы распространения могут быть разными. Столь же разнообразны и методы изучения бедности. В настоящем исследовании ${ }^{1}$ представлены результаты анализа высказываний россиян в Интернете по поводу особенностей богатства

${ }^{1}$ Исследование проводилось в рамках научно-исследовательского проекта «Наблюдая за русскими: экономические реалии», реализуемого на кафедре экономической социологии и менеджмента социологического факультета МГУ им. М. В. Ломоносова с 2016 г. Проект ориентирован на изучение различных аспектов экономического поведения россиян, а также восприятие ими разнообразных экономических явлений на основе анализа интернет-коммуникаций. Контент-анализ интернет-пространства как один из этапов данного проекта собирался в сентябре 2017 г. -январе 2018 г. В проекте задействованы преподаватели и магистранты кафедры (Д. Еркина, А. Зинченко, Ю. Иваничева, А. Корастылева, В. Матевеева, С. Мурадян, М. Пивоварова, Е. Федорова) и бедности в стране, отношений между богатыми и бедными, а также факторов, непосредственно воздействующих на данные социальные явления.

Нынешняя социально-экономическая ситуация в стране характеризуется значительным сокращением реальных доходов населения и увеличением бедности. По данным Федеральной службы государственной статистики, в 2014 г. число россиян с доходом ниже прожиточного минимума в России составляло 16,1 млн чел. (11,2\% всего населения), в 2015 г. - 19,5 млн чел. $(13,3 \%)$, в 2016 г. - 19,6 млн чел. (13,4\%), в первом полугодии 2017 г. - уже 21,1 млн чел. $(14,4 \%)^{2}$.

Проблема усугубляется массовым сокращением расходов на оплату труда, затронувшим в 2015 г., по данным социологических исследований, почти $30 \%$ российских компаний (чаще всего экономят на рядовых сотрудниках). В 17\% организаций заработную плату сотрудникам сократили на 20-30\%, хотя ранее о таком масштабе сокращений думали лишь в $13 \%$ компаний [Бибков, 2015].

\section{Данные традиционных опросов по проблемам богатства и бедности}

По информации ФОМ, население за последние 3-4 года стало менее негативно оценивать динамику своего материального положения: если в декабре 2015 г. и 2016 г. доля лиц, считающих, что их материальное положение за последние два-три месяца ухудшилось, составляло соответственно 49 и $32 \%$, то в июле 2017 г. $-28 \%$. Доля лиц, указывающих, что их материальное положение за последние месяцы практически не изменилось, составила в июле 2017 г. 64\% (в конце 2015 г. - 41\%, а по итогам 2016 г. $-56 \%)^{3}$. Схожие данные получены при мониторинге социально-экономического положения и социального самочувствия населения России НИУ ВШЭ: в сентябре 2017 г. доля населения, характеризующего материальное положение своих семей как плохое и очень плохое

2Данные Федеральной службы государственной статистики [Эл. pecypc]. URL: http://www.gks.ru/wps/wcm/connect/rosstat_main/rosstat/ru/statistics/population/level/\# (дата обращения: 20.01.2018).

3Данные опроса Фонда общественного мнения «ФОМнибус», 2015-2017 гг. Опрос граждан РФ от 18 лет и старше. 43 субъекта РФ, 100 населенных пунктов, 1500 респондентов [Эл. ресурс]. URL: http://fom.ru/Nastroeniya/12462; URL: http://fom.ru/ Ekonomika/13115 (дата обращения: 11.01.2018). 
(бедные по самооценке материального положения), составила 23\%, доля семей, испытывающих затруднение с приобретением одежды или продуктов питания, $-38 \%$. По данным мониторинга, с начала 2016 г. отсутствуют статистически значимые изменения в показателях бедности, но к осени 2017 г. увеличилась доля граждан, позитивно оценивающих свое материальное положение: в сентябре 2017 г. 15\% опрошенных назвали его хорошим или очень хорошим (в сентябре 2016 г. - 11\%) [Овчарова и др., 2017. С. 25].

При этом, по данным исследования Института социологии РАН, доля лиц, экономящих на покупке продуктов питания, а также одежды и обуви, сократилась весной 2017 г. по сравнению с тем же периодом 2016 г. с 51 до $35 \%$ и с 61 до $47 \%{ }^{4}$.

Важно отметить, что усталость от перманентного кризиса компенсируется тем, что россияне ищут и находят новые источники хорошего настроения. Так, ВЦИОМ в августе 2017 г. зафиксировал исторический максимум уровня счастья у россиян: $84 \%$ опрошенных ощущают себя счастливыми (среди респондентов с достатком -94\%, малообеспеченных - $61 \%$ ). На уровень счастья, безусловно, влияет материальное положение, но важнее наличие семьи $(33 \%)$, хорошее физическое самочувствие $(22 \%)$ и дети (14\%). Недовольство жизнью связано, прежде всего, с проблемами материального характера (10\%), низкой заработной платой $(6 \%)$, состоянием здоровья (6\%) и плохим положением дел в стране $(6 \%)^{5}$.

Проблема антагонизма богатства и бедности остается попрежнему актуальной. Так, по данным ВЦИОМ, распределение доходов в нашем обществе большинство соотечественников считают несправедливым (однако за 25 лет эта доля несколько снизилась: с $84 \%$ в 1990 г. до $77 \%$ в 2015 г. $)^{6}$. При этом $73 \%$ россиян полагают, что разница в доходах продолжает увеличиваться, и $63 \%$ - что это мешает развитию страны

${ }^{4}$ Кудрин К. Россияне адаптировались к экономической ситуации//Известия. 2017 11 июля. [Эл. ресурс]. URL: https://iz.ru/616017/kirill-kudrin/rossiian-spasaet-ogorod (дата обращения: 15.11.2017).

${ }_{5}^{5}$ Счастье в России: мониторинг// Пресс-выпуск ВЦИОМ № 3431. 2017. 1 авг. [Эл. pecypc]. URL: https://wciom.ru/index.php?id=236\&uid=116335 (дата обращения: 15.11 .2017 ).

${ }^{6}$ Богатые и бедные - вчера и сегодня // Пресс-выпуск ВЦИОМ № 2878. 2015. 14 июля [Эл. pecypc]. URL: https://wciom.ru/index.php?id=236\&uid=115317 (дата обращения: 18.12.2017).

Данные опроса Фонда общественного мнения «О бедных, богатых и разнице в доходах». 2017. 18 окт. [Эл. ресурc]. URL: http://fom.ru/Ekonomika/13815 (дата обращения: 20.01.2018).
По данным опроса «Левада-центра», напряженность между богатыми и бедными $41 \%$ респондентов оценили как «очень сильную» (в 1994 г. - 18\%). О «некоторой напряженности» говорят $35 \%$ опрошенных (в 1994 г. - 32\%), считают ее «не очень сильной» $-14 \%$ (в 1994 г. - 30\% $)^{8}$. Получается, что 90\% опрошенных в той или иной мере признают существование этой проблемы.

\section{Специфика анализа интернет-коммуникаций как метода получения социологической информации}

Опрос как метод социологического исследования имеет ряд особенностей: исследователь при общении часто предлагает вопросы респонденту, которые сами по себе у последнего обычно не возникают.

Анализ интернет-коммуникации, в отличие от опроса, представляет собой наблюдение за вербальным поведением и включает только небольшие элементы опросов, причем вопросы формулируют непрофессионалы, исходя из своих интересов. Чаще всего эти интересы далеки от познавательной деятельности ученых и касаются тех аспектов, обладание знанием о которых может помочь людям в разных жизненных ситуациях. Можно сказать, что в этом случае происходит «практическая операционализация» вопросов.

Изучение сетевых сообществ для выявления мнений пользователей актуально, потому что включенность в них создает специфический гибридный мир, в котором живут миллионы людей. Сегодняшнее состояние включенности людей в социальные медиа (вне зависимости от уровня дохода, профессионального статуса, пола и т.д.) позволяет предполагать, что в сети формируется вполне репрезентативная аудитория, а не отдельные виртуальные сообщества. Изучение этого мира становится в современных условиях важнейшей задачей социологии. Согласно отчету Digital in 2017: Global Overview, из 7,476 млрд населения мира относятся к активным пользователям социальных медиа 2,789 млрд $(37 \%)^{9}$. По данным Всероссийского омнибуса GfK,

8 Лория Е. Богатые стали раздражать россиян вдвое больше//Данные портала Левадацентр. 2016. 26 июля [Эл. ресурc]. URL: https://www.levada.ru/2016/07/26/bogatye-stalirazdrazhat-rossiyan-vdvoe-bolshe/ (дата обращения: 18.12.2017).

9 Обзор «Digital in 2017: Global Overview» [Эл. pecypc]. URL: https://wearesocial.com/ sg/blog/2017/01/digital-in-2017-global-overview (дата обращения: 19.01.2018). 
к началу 2018 г. аудитория интернет-пользователей в России среди населения в возрасте 16+ составила 87 млн чел. $(72,8 \%)$. Так как среди молодежи уровень пользования Интернетом достиг предела 98\% (2015 г.), аудитория растет в основном за счет людей старшего возраста. За последний год среди людей в возрасте от 55 лет и старше доля пользователей Интернета увеличилась на четверть, а мобильного Интернета - вдвое ${ }^{10}$. По данным ФОМ, на январь 2016 г. 87\% всех российских интернет-пользователей посещают социальные сети, при этом доля тех, кто делает это раз в день и чаще, по всем возрастным группам составила $66 \%{ }^{11}$.

Россия признана страной с самой активной интернет-аудиторией: согласно мониторингу Brand Analytics, количество активных авторов в социальных медиа в мае 2017 г. составило 38 млн чел. (они сгенерировали за месяц 670 млн сообщений). Превалирующая доля контента сосредоточена в социальных сетях - 470737 тыс. публикаций $(70,2 \%$ от совокупного объема упоминаний в социальных медиа $)^{12}$.

Каковы же методологические и методические особенности анализа сообщений в Интернете по проблеме бедности? Во-первых, данная проблема, несмотря на свою актуальность, не является в сети центральной и как самостоятельная не обсуждается. Высказывания о богатстве и бедности возникают в процессе обсуждения других проблем, например, нового закона (поправок к закону), политических новостей, новинок на потребительском рынке и др. Это обусловило сложность и некоторую субъективность определения выборки. В анализе участвовали те сообщества и те темы обсуждения, которые виделись как смежные с проблемами богатства и бедности. При этом за рамками анализа оставались высказывания из различных дискуссий, названия (или общая тема) которых никак не соотносились с предметом нашего исследования.

${ }^{10}$ Игнатьева Н., Федотов А. Проникновение Интернета в России: итоги 2017 года// Пресс-релиз Всероссийского омнибуса GFK. 2018. 16 янв. [Эл. ресурс]. URL: http://www.gfk.com/fileadmin/user_upload/dyna_content/RU/Documents/Press Releases/2018/GfK_Rus_Press_Release_Internet_Penetration_in_Russia_2017-2018.pdf (дата обрашения: $\overline{19} .01 . \overline{2} 018$ ).

${ }^{11}$ Данные опроса Фонда общественного мнения 15-19 января 2016 г. «Онлайн практики россиян: социальные сети». 2016. 28 янв. [Эл. ресурc]. URL: http://fom.ru/ SMI-i-internet/12495 (дата обращения: 20.01.2018).

${ }^{12}$ Социальные сети в России, лето 2017: цифры и тренды. 2017. 29 июня. [Эл. ресурс]. URL: http://blog.br-analytics.ru/sotsialnye-seti-v-rossii-leto-2017-tsifry-i-trendy/ (дата обращения: 20.01.2018).
Во-вторых, в интернет-коммуникациях редко присутствуют нейтральные оценки: как правило, социальные медиа представлены поляризированными точками зрения.

В-третьих, за пределами исследования остались проблемы гастарбайтеров, которые в России сталкиваются с бедностью в ее классическом капиталистическом понимании (мы анализировали только русскоязычные сайты).

Традиционно социологи различают абсолютный и относительный типы бедности. Если взять за основу определение бедности Э. Гидденса (это «условия отсутствия доступа к благам, которые считаются “базовыми” или “нормальными” в обществе» [Giddens, Satton, 2017. С. 103]), то разграничение двух данных типов будет вполне логичным. Понятие абсолютной бедности связано с базовыми условиями существования. Так, люди, испытывающие недостаток в продуктах питания и одежде, живут в абсолютной бедности. И тем не менее исчерпывающие критерии абсолютной бедности отсутствуют, так как определение базовых потребностей зависит от культуры. Поэтому большая часть современных социологов используют понятие относительной бедности, которая соотносится с общим стандартом «нормальной» жизни в конкретном обществе. Основоположником данного подхода считают П. Таунсенда, указавшего, что признаками бедности выступают лишения, которые испытывают бедные семьи и которые в соответствующей культуре рассматриваются как свидетельства бедности [Townsend, 1979, 2010].

По мнению Гидденса, теории, объясняющие феномен бедности, разделяются на «обвиняющие жертву» и «обвиняющие систему» [Giddens, Satton, 2017. С. 104]. В первом случае индивид сам «виноват» в том, что беден: общество предоставило ему шансы на успех, а он, например, из-за лености ими не воспользовался. Во втором случае «виноваты» скорее социальноэкономические условия. Как будет показано далее, участники интернет-коммуникаций однозначно относятся к группе обвиняющих систему. В ряде случаев люди, пользуясь анонимностью, откровенно говорят о себе то, что невозможно услышать в реальном общении. Но никто из них не выложил в сеть признания о том, что он сам виноват в своем бедственном положении.

Представляя собой специфическую площадку для обсуждений, Интернет тем не менее не может в полной мере быть назван 
«зеркалом» социальной реальности; это - особый гибридный мир. Здесь некоторые вопросы неуместны, а другие обсуждаются под специфическими углами зрения. Часто сообщения возникают спонтанно в ответ на уже опубликованные посты или статьи. При этом обсуждение начинает идти по неожиданным сценариям, а многие логически связанные аспекты проблемы выпадают из поля зрения интернет-пользователей. Общение в сети задает особые ракурсы рассмотрения проблем, не схожие ни с теми, которые присутствуют в научном дискурсе, ни с характерными для реального повседневного общения людей.

\section{О программе исследования интернет-коммуникаций}

Объектом нашего эмпирического исследования выступили сообщения (300 информационных блоков) - статьи, посты и комментарии, размещенные пользователями в социальных медиа - социальных сетях, блогах и на форумах, посвященные двум взаимосвязанным темам: 1) «Бедность и бедные в современной России» и 2) «Богатство и богатые в современной России». Предметом исследования послужили оценочные и содержательные мнения авторов сообщений по данным темам. Целью исследования стало выявление особенностей восприятия богатства и бедности, а также богатых и бедных в российском интернет-пространстве. Исследование проводилось в конце 2017 г. - начале 2018 г. методами контент-анализа и качественного анализа интернет-сообщений. Были обработаны сообщения за 2013-2017 гг. и проведены следующие исследовательские процедуры:

1) отбор из всей информационной совокупности сообщений по исследуемым темам;

2) выделение факторов, объясняющих причины исследуемых феноменов, путем многоступенчатой содержательной группировки соответствующих высказываний в сообщениях;

3) выделение (также путем группировки) индикаторов, с которыми у авторов сообщений ассоциируются исследуемые феномены;

4) подсчет появления индикаторов в сообщениях (единиц анализа) в количестве слов (единицы счета) и определение их удельного веса в процентах;

5) подсчет оценочных характеристик исследуемых феноменов (единиц анализа) в каждом из сообщений (единицы счета) и определение процентного соотношения этих характеристик, в первую очередь, характера оценок - позитивного, негативного или нейтрального;

6) качественный анализ наиболее репрезентативных высказываний, различающихся по своим оценочным и содержательным характеристикам.
Выборку составили наиболее часто посещаемые интернетресурсы, напрямую не связанные с обсуждением политических проблем, поддержкой определенных политических сил или идеологий.

Были проанализированы статьи из электронного журнала «ВОС» (Вокруг Огромная Страна, http://w-o-s.ru/) - аудитория около 80000 читателей; группа «Лентач» социальной сети «ВКонтакте» (https://vk.com/public29534144) - 1747655 подписчика; ответь пользователей сайта The Question (https://thequestion.ru/ru/feed) - 356665 подписчиков, ежемесячное количество посетителей форума - 411954; сообщения и комментарии к ним в форуме Леди@Mail.ru - ежемесячное количество посетителей 15547160 чел.; посты и комментарии на сайте PolitUserForum (https://www.polituserforum.ru/) - 443 зарегистрированных пользователя, ежемесячное количество посетителей - 4275 чел.; официальная группа сайта «Финансовый гений» ВКонтакте (https://vk.com/fingeniy) - 3547 подписчиков; ответы и комментарии к вопросам Ответы.Мail.ru (ежемесячное количество посетителей на январь 2016 г. - 88163078 чел., январь 2017 г. - 80565522 , январь 2018 г. - 69087078) и портала «Мировой кризис - хроника и комментарии» (http://worldcrisis.ru/\#) - 37242 зарегистрированных пользователя. Всего было проанализировано 300 статей и постов и комментариев к ним.

\section{Проблема бедности в российском интернет-пространстве}

Первая тема - «Бедность и бедные в современной России»была ориентирована на наиболее острые социальные проблемы, и собранные по ней материалы задавали содержательные приоритеты всего исследования.

В проанализированном массиве о бедности удельный вес информации, непосредственно затрагивающей проблемы бедности и ее социально-экономического контекста, - всего 16,2\%. При этом 58\% постов, комментариев и т.д. генерируют женщины. Но небольшой объем информации отнюдь не говорит об отсутствии интереса к проблеме: пользователи социальных сетей рассматривают бедность в более широком контексте, связанном с падением уровня жизни и социально-экономической ситуацией в стране и в мире, а также увязывают ее с определенной причиной падения уровня жизни (например, инфляцией, снижением заработных плат, ростом налогов и т.д.).

В ходе проведенного анализа были выявлены три ключевых фактора, названных пользователями в качестве причин бедности:

1) снижение заработной платы, которое влечет за собой толерантное отношение к проблеме «серых» зарплат;

2) рост инфляции, «невидимый» официальной статистикой (инфляция приводит к существенному удорожанию стоимости 
товаров и услуг, причем не абстрактной потребительской корзины, а к реальному сужению возможностей людей, в результате чего им приходится перестраивать потребительские стратегии);

3) экономическая политика Правительства и Президента РФ (обусловленность проблемы бедности как внешними факторами мировой политической и экономической обстановкой, санкциями в отношении страны и др., так и внутренними - структура экономики, отсутствие преобразований, коррупция и т.д.).

В проанализированных интернет-форумах превалирует информация по таким индикаторам, как «деньги» $(30,7 \%$ общего объема информации), «доход» $(28,8 \%)$, «экономия» $(17,0 \%)$, «нищета» $(16,0 \%)$. Таким образом, бедность ассоциируется преимущественно с товарно-денежными отношениями и потребительским поведением и практически не связывается с проблемами миграции, доступа к образованию и вообще с социокультурными факторами (табл. 1).

Таблица 1. Распределение объема и удельного веса информации о бедности и бедных

\begin{tabular}{|l|c|c|}
\hline \multicolumn{1}{|c|}{ Индикатор } & $\begin{array}{c}\text { Объем информации } \\
\text { в словах }\end{array}$ & $\begin{array}{c}\text { Удельный вес } \\
\text { информации, \% }\end{array}$ \\
\hline Деньги & 1074 & 30,7 \\
\hline Доход & 1008 & 28,8 \\
\hline Экономия & 594 & 17,0 \\
\hline Нищета & 558 & 16,0 \\
\hline Работающая бедность & 150 & 4,3 \\
\hline Кредит & 66 & 1,9 \\
\hline Бедность и образование & 30 & 0,9 \\
\hline Мигранты & 18 & 0,4 \\
\hline Итого: & $\mathbf{3 4 9 8}$ & $\mathbf{1 0 0}$ \\
\hline
\end{tabular}

В процессе анализа был сделан вывод о том, что налицо общее превалирование негативных высказываний о бедности $(54,9 \%)$. Среднестатистический интернет-пользователь крайне импульсивно высказывает свое негодование по поводу того или иного закона, его отдельной статьи, роста налогов и т.д. Однако значительно число и нейтральных $(21,5 \%)$, и положительных $(23,6 \%)$ оценок, которые, правда, относятся не столько к бедности, сколько к бедным.

Негативные оценки связаны в первую очередь с социальной политикой государства, а также с отсутствием социального партнерства. Тем самым интернет-пользователи в целом относятся к людям, «обвиняющим систему» в том, что касается проблемы бедности. Несмотря на существующую тенденцию к индивидуализму, в общественном сознании со времен СССР осталось иждивенческое отношение к государству, которое обеспечивало людей работой, жильем и т.д. Также пользователи указывают, что общая поддержка действующего Президента и Правительства обусловлена тем, что большинству «плевать на коррупцию и экономику. Им важны внешнеполитические понты... Люди одобряют действия воровской власти, им нравится этот президент, его друзья, дума, правительство, пропаганда, ненависть к гомосексуалам, мигрантам, Западу» (Евгения, 38 лет, маркетолог).

Органически продолжает эту критику и переводит ее в более прагматичное русло отсутствие желания сотрудничать с властями. Если государство не выполняет свои обязанности перед народом, то зачем быть законопослушным, в частности, платить налоги? Так, изрядное количество сообщений в сети оправдывают систему нелегальных выплат за труд или «серых» зарплат. Приведем одно из них: «Учитыввая, что пенсии, того и гляди, отменят, а кредит при нынешней ставке брать бессмысленно, то серая зарплата ничем не плоха. Более того, можно самостоятельно выбрать схему сбережений, чтобы затем более раиионально инвестировать их... Плюс к этому для работающих граждан экономически выгоднее не пользоваться государством как посредником, а самостоятельно копить себе на пенсию, оплачивать медичину и т.д.» (Борис, 46 лет).

В рамках исследования было выявлено очевидное отрицательное отношение общественности к феномену бедности, но к самим бедным и неимущим проявляются жалость и сопереживание. Этим сегодня нередко пользуются мошенники, запрашивая в сети помощь у сердобольных россиян на лечение несуществующих болезней и пр.

Именно в рамках анализа темы бедности и бедных проявилась главная особенность интернет-коммуникаций - органичное сочетание описательности и прагматизма. В Интернете люди прежде всего делятся своим опытом, а не дискутируют на обобщенные наукообразные темы. Они считают, что их опыт может быть интересен другим. Причем в ряде случаев этот опыт пользователь 
может просто сравнить с собственным или почерпнуть из него что-то полезное для себя. Людей не интересует абстрактная проблема бедности. Они готовы рассказать о том, как стали бедными, а также поделиться своим опытом выживания в условиях бедности. Часть высказываний носит описательный характер.

«Кризис он как грянул неожиданно, так половина заказчиков отвалилась. А потом вторая волна пошла-и все, вместо хать в иентре -жизнь в области, вместо "Чиваса" - "Столичная". В первую очередь я отказался от ресторанов. Раньше питался исключительно в них. Потом я в них только ужинал. А потомвсе, жрать только дома. Сейчас экономлю вообще на всем. Мне ничего особо не надо. На мясо денег пока хватает, слава богу, на “Столичную” - тоже» (Олег, 30 лет, безработный).

«Вот вам история про бедных людей: нормальную зп порезали на 50\%, на аренду [квартиры] уходит 90\%, на еду остается 7 тыш в месяи, и это курочка с макаронами каждый день в лучшем случае и бутылка беленькой по пятницам с друзьями! И никаких поездок, одежды, досуга, развлечений, какое, блин, в кино сходить, щаз, вообще из дома не выйти -за проезд только 2 тысячи в месяи уходит ...Если раньше мог себе позволить сходить в бар с друзьями, сейчас только посиделки по домам, бюджет на такие посиделки 1-2\% от оставшихся денег. Одежду не покупаю совсем, эта не порвалась ещеџ (Сергей, 24 года, геолог).

Наряду с подобными жалобами Интернет наполнен постами, в которых люди описывают, как планируют (или не планируют) бюджет, используют скидочные программы различных компаний, экономят на еде. В этих высказываниях есть реальная прагматическая сторона-возможность что-то позаимствовать из рецептов выживания в условиях хронического безденежья. К этому типу принадлежит большинство высказываний по теме. Приведем некоторые из них.

«Бюджет я особенно не планирую, но есть финт: стараюсь все покупать с кредитки, но не вылезать за грейс. Очень дисииплинирует, учит считать деньги. Сейчас я пробую работать дальше, ну а если не выйдет, то бежать. Никогда не поздно заняться духовнымм ростом в тихой обители» (Олег, 30 лет, безработный).
«...Стараюсь выбирать время сеанса в кинотеатре преимущественно в ранние часы, так же тщательно подбираю киноленты к просмотру. Часть фильмов смотрю дома, после того как заканчивается их прокат в кинотеатре» (Дарья, 30 лет, ассистент).

«В последнее время я перестала совершать импульсивные покупки...

- перестала покупать каждое утро кофе в Старбакс. Поняла, что небольшие на первый взгляд 300 рублей 5 раз в неделюэто 6000 рублей в месяи!

- урезала бюджет на развлечения, уменьшила количество посещуений ресторанов, кафе. Стараюсь не пользоваться столовой в офисе;

- отказалась от покупки колбасы, йогуртов, творожков, снеков» (Дарья, 30 лет, ассистент).

«Первые два года пытался изврашаться, готовить что-нибудь вкусненькое - котлеты с начинкой, курииу в каком-нибудь соусе и все такое... Последний год начал покупать макаронь и полуфабрикаты - котлеты там, наггетсы, сосиски. В иелом, если не выпендриваться, не питаться пельменями "Цезарь" со сметаной из “Избенки”, получается 7000-8000 в месяи на еду... Если с деньгами совсем плохо, покупаю пачку фасоли и тушу ее так же, как макароны, с луком и помидорами... Очень сытно и вкусно» (Яша, студент, 19 лет).

Любопытно, что, несмотря на наличие огромного числа ресторанов с итальянской кухней, где паста - традиционное и не самое дешевое блюдо, в сознании соотечественников еще с советских времен эта еда ассоциируется с отсутствием денег и урезанием бюджета.

\section{Инфляция и бедность глазами интернет-пользователей}

Один из интересных аспектов восприятия проблем бедности и богатства - это обсуждение инфляции как фактора, непосредственно влияющего на материальное положение людей. С ней было связано $24,6 \%$ информации о падении уровня жизни. В отличие от общего контента о бедности, который, как отмечалось, продуцируют, как правило, женщины, основная часть высказываний об инфляции и подорожании товаров и услуг 
в интернет-источниках принадлежит мужчинам (60\%). Большая их часть встроена в высказывания на тему «отказа от товаров/ услуг/развлечений, доступных ранее» и «положительные/отрицательные отзывы об экономике страны в целом», либо это комментарии к «высказываниям по поводу ухудшения/улучшения условий жизни». Под влиянием кризиса и роста стоимости товаров и услуг пользователи вынуждены были резко снизить импульсные покупки и начать экономить на развлечениях и досуге, а в целом - существенно скорректировали потребительские стратегии. Эти процессы затронули различные половозрастные и доходные группы.

Регулирование инфляции - это значимая составляющая макроэкономической политики государства. Поэтому снижение своего жизненного уровня и общее ухудшение экономической ситуации в стране пользователи связывают с неправильными и неэффективными действиями Правительства и властной элиты в целом, а также с проблемой коррупции.

«Все экономические проблемы в России - следствие неумелого руководства, поэтому и инфляция у нас постоянно высокая. А неумелое руководство сидит вследствие отсутствия конкурентной политической среды... Монополизированная недиверсифицированная экономика, управляемая неучами, никак не может выйти на стабильный рост, что может снизить инфляциию. Честно сказать, экономическими институтами у нас управляют не совсем неучи, а даже, нередко, наоборот, но они связаны по рукам и ногам захватившими власть политиками, которые затянули страну в “голландскую болезнь”, поделили меж собой самые выгодные отрасли и пытаются удержаться за власть, устраивая то аннексии соседних территорий, то войны, что привело к санкциям против нашей страны, снижению инвестиций и растрате средств... Ну и, конечно, про коррупцию надо не забывать: не менее 10\%, а скорее всего более, мы почти в каждом товаре имеем коррупционной наценки... Так что пока не появится реальной конкурентной политической средь, которая также поспособствует демонополизации и декоррумпинизации экономики, с инфляцуией будет у нас полный швах. Всё остальное - полумеры» (Алексей, 39 лет, юрист).
«Я захожу в магазин, чтобы купить мою любимую замороженную пициу “Ристоранте”. Она стоит 112 рублей. Вдруг меня пронзает мысль: "Надо позаботиться о будущем! Пусть мне будет что есть через три года!'” И вместо пициы я откладываю 112 рублей во вклад на три года. Я уверен, что через три года я сниму эти деньги, пойду в магазин и куплю эту пициу и ещзе баночку газировки.

Проходит три года. Проиенты капают. Я снимаю со счета 145 рублей, иду в магазин, а пиция стоит уже 264 рубля. Я уже не могу ее купить на свои сбережения. Ценовая инфляиия сожрала мою пиииу и выпила баночку газировки. Может показаться, что всё тлен: инфляция сжирает деньги, ОФЗ дают мизерную доходность, хочется лечь ровно в банковскую ячейку и заснуть летаргическим сном» (Артем, 27 лет, инвестор).

Инфляция как экономическое явление и одновременно недовольство инфляцией как социальное явление сопровождали весь ход хозяйственных преобразований в стране. Темпы инфляции менялись, но никогда не достигали приемлемого уровня. В конце 2017 г. в результате принятых Правительством мер инфляция сократилась до минимального уровня с начала 1990-х годов. Это не могло не сказаться на потребительском поведении. При этом возникает вопрос о том, как это объективное изменение экономической реальности отразится в интернет-коммуникации? Запоздает ли осознание того, что цены стали расти значительно медленнее, в сравнении с реальным положением дел? И если запоздает, то насколько? Или в сети быстро появятся посты, отражающие новые реалии, что называется «с прицелом на будущее», т.е. рецепты выживания в условиях относительно стабильной системы цен? Ответы на эти вопросы могут дать будущие исследования, ориентированные на сравнительный анализ условий жизни и стереотипов восприятия людей в периоды с разными экономическими условиями (уровень инфляции, проценты по кредиту, курс валюты и др.).

\section{Проблема богатства}

В отличие от проблемы снижения уровня жизни проблеме богатства и отношения к богатству в сетях уделяется значительно меньше внимания. Из общего объема обработанной информации по богатству только 10,4\% обсуждений посвящены напрямую теме 
исследования. Анализ удельных весов по каждому содержательному признаку позволяет сделать следующие выводы (табл. 2).

\section{Таблица 2. Распределение объема и удельного веса} информации о богатстве и богатых

\begin{tabular}{|l|c|c|}
\hline \multicolumn{1}{|c|}{ Индикатор } & $\begin{array}{c}\text { Объем информации } \\
\text { в словах }\end{array}$ & $\begin{array}{c}\text { Удельный вес } \\
\text { информации, \% }\end{array}$ \\
\hline Высокие доходы & 481 & 25,4 \\
\hline Моральные качества богатых & 350 & 18,5 \\
\hline Элитарный уровень потребления & 290 & 15,3 \\
\hline Обладание властью & 170 & 9,0 \\
\hline Накопления & 165 & 8,7 \\
\hline $\begin{array}{l}\text { Престижность социального } \\
\text { статуса }\end{array}$ & 125 & 6,6 \\
\hline Совокупностьсоциальныхсвязей & 112 & 5,9 \\
\hline Методы достижения богатства & 85 & 4,5 \\
\hline $\begin{array}{l}\text { Разрыв между богатыми и бед- } \\
\text { ными }\end{array}$ & 62 & 3,2 \\
\hline Отношение богатых к бедным & 54 & 2,9 \\
\hline Итого: & $\mathbf{1 8 9 4}$ & $\mathbf{1 0 0}$ \\
\hline
\end{tabular}

Наибольшее число упоминаний получил индикатор «высокие доходы» $-25,4 \%$, далее располагаются такие индикаторы, как «моральные качества богатых» $(18,5 \%)$, «элитарный уровень потребления» $(15,3 \%)$ и «обладание властью» $(9,0 \%)$. Наименьшее количество упоминаний касается следующих содержательных характеристик: «методы достижения богатства» $-4,5 \%$; «разрыв между богатыми и бедными» - 3,2\% и «отношение богатых к бедным»-2,9\%. В дискуссию об отношении к богатству и богатым одинаково вовлечены как мужчины (48\%), так и женщины (46\%), еще у 6\% пользователей по профилям установить пол не удалось.

На наш взгляд, наиболее значимым результатом исследования стало то, что положительные (49\%) и нейтральные (33\%) оценки богатства преобладают над отрицательными ( $18 \%$ интернет-пользователей). В проанализированном массиве данных к богатым людям относятся с уважением и одобрением, воспринимая их достаток как вознаграждение за сверхусилия и напряженную работу: «У богатых работы много, по 12 часов» (Иннокентий, 25 лет); «ленивым сложно разбогатеть... Сидючи на диване богатым не станешь» (Анастасия, 31 год); «...Если человек сумел заработать богатство сам - это сильный человек. Сильных людей надо уважать» (Иннокентий, 25 лет). Такая оценка богатства в российском обществе может свидетельствовать об изменении сознания россиян в сторону принятия формирующихся принципов рыночной экономики и идеи предпринимательства как способа достижения богатства.

Стремление к богатству становится важнейшей жизненной стратегией и побуждает людей больше работать и изобретать самые разные способы для обретения высокого имущественного статуса: «В любом случае материальное богатство - это ицель, о которой мечтает и к которой стремится абсолютное больиинство из живущих на земле. Многие стесняются говорить об этом вслух, но внутри себя вынашивают робкие надежды, в коние концов, стать богатыми (Аноним, 28 лет).

Примечательно, что результаты многих социологических исследований, например, Института социологии РАН «О чем мечтают россияне», подтверждают позитивное отношение к богатству, стремлению к обеспеченной жизни. Самая популярная мечта россиян - «жить в достатке, иметь возможность тратить деньги, “не считая копейки”» [О чём мечтают россияне..., 2013. C. 22]. Богатство перестает быть жупелом, и с ним, судя по отсутствию соответствующих высказываний, никто не собирается бороться: «Я совершенно не хочу ничего отбирать например, у известных богатых художников, музыкантов и прочих людей, действительно честно заработавших свое состояние...» (Вебсталкер, 31 год).

Здесь следует снова обратить внимание на особенности интернет-коммуникации. В личных беседах люди сплошь и рядом ругают богатых, доходит даже до вполне конкретных призывов к «раскулачиванию» олигархов. В принципе, «шариковский» лозунг «Взять все, да и поделить!» не может потерять своей популярности в условиях сильной имущественной дифференциации и ощущения того, что кто-то другой получает доходы, причитающиеся тебе. Но оказалось, что об этом не принято высказываться в сети.

Причины этой «застенчивости» могут быть самыми разными. Одной из них вполне вероятно может служить прозападная ориентация многих протестных сообществ в Интернете: они не хотят иметь ничего общего с коммунизмом и социализмом. Выступая 4 ЭКО. - 2018. - № 3 
против российских властей, эти сообщества не могут назвать социальное неравенство как главное зло, так как предлагаемое ими направление социально-экономического развития страны как раз эту проблему решить не сможет: ведь неравенство характерно для всех, даже очень «правильных», с их точки зрения, капиталистических государств. Однако проанализированные сайты, блоги и порталы не имели явной протестной или «прозападной» направленности.

Полученные данные могут свидетельствовать о том, что в условиях реального снижения уровня жизни российских интернет-пользователей в первую очередь волнуют проблемы собственного выживания, поиска способов поддержания сформированных в «тучные нулевые» стандартов потребления, что переводит на второй план обсуждение вопроса о причинах социального расслоения и поиск ответа на извечный вопрос «Кто виноват?». Можно констатировать, что в сети сформировался особый стиль обсуждения проблем, особый дискурс, в рамках которого призывы против богатых оказываются неуместными.

\section{Заключение}

Результаты проведенного исследования позволяют сформулировать ряд важных и интересных выводов

Во-первых, негативная оценка бедности, демонстрируемая данными мониторингов, так же явно проявляется и в интернетаудитории, в то время как отношение к богатству и богатым, к социальной дифференциации общества представлено более нейтральными оценками. Проблема справедливого распределения доходов отходит на второй план, а на передний выдвигается возможность поддерживать приемлемый уровень жизни в непростых экономических условиях.

Во-вторых, несмотря на преимущественно негативную оценку деятельности Правительства и понимание отсутствия институциональных преобразований в структуре российской экономики, интернет-пользователи не демонстрируют ярко выраженные протестные настроения. Скорее проблемы бедности и богатства обсуждаются в рамках личных переживаний и опыта пользователей.

В-третьих, общение в сети предполагает прагматическую направленность. Здесь не обсуждаются общие проблемы социально-экономического и социально-политического характера.
Бедность и богатство в анализируемом текстовом массиве воспринимаются сквозь призму потребительского поведения с целью поиска возможностей для удовлетворения потребностей людей.

В-четвертых, население привыкает к перманентному кризису, перестает остро ощущать резкое снижение материального достатка и покупательной способности, оно ищет различные формы адаптации и способы выживания в современных условиях.

Проведенный контент-анализ источников в социальных медиа позволяет также сформулировать исследовательские задачи для дальнейших социологических исследований.

Требует проверки вопрос об отношении к богатым. В условиях углубления социального неравенства важно понять, действительно ли в сознании интернет-пользователей происходит принятие существующего положения вещей, формируется ли более позитивное восприятие богатства и богатых, или же общение в социальных медиа заставляет людей следовать социально одобряемой в сети точке зрения и не высказывать реального отношения к богатым.

Вторым возможным развитием настоящего исследования является лонгитюдный анализ восприятия изменений параметров бедности и богатства интернет-пользователями. Восприятие часто отстает от быстро меняющейся социальной реальности. Здесь можно вспомнить ситуацию начала XXI столетия, когда значительная часть населения в условиях начавшегося экономического роста воспринимала существующее положение как кризис. Однако в ряде случаев люди могут и предугадывать перемены, и высказывать соответствующие предположения. Гибридный мир, созданный интернет-коммуникациями, может позволить реализоваться обеим возможностям, и, с социологической точки зрения, важно понять, какая из этих альтернатив восприятия мира будет более адекватной общению в сети.

\section{Литература}

Бибков $A$. Почти треть компаний заявила о начале сокращения зарплат Данные портала РБК. 2015. 9 апр. [Эл. ресурc]. URL: https://www.rbc.ru/eco nomics/09/04/2015/55267fd09a7947e81040e8f3 (дата обращения: 18.12.2017).

Овчарова Л.Н., Бирюкова С.С., Селезнева Е.В., Абанокова К.Р., Абрамова Н.В. Население России в 2017 году: доходы, расходы и социальное самочувствие. Мониторинг НИУ ВШЭ. 2017. нояб. /Под ред. Л.Н. Овчаровой. М., НИУ ВШЭ, 2017. 51 с.

О чём мечтают россияне: идеал и реальность / Под ред. М. Горшкова, Р. Крумма, Н. Тихоновой. М.: Весь мир, 2013. 400 с. 
Giddens A., Satton P. Essential Concepts in Sociology. $2^{\text {nd }}$ Edition. Polity Press, 2017. $240 \mathrm{p}$.

Townsend P. Poverty in the United Kingdom: A Survey of Household Resources and Standards of Living. Harmondsworth, Penguin, 1979. 1216 p.

Townsend P. Meaning of Poverty // The British Journal of Sociology. 2010. № 61. Pp. 85-102.

Статья поступила 29.01.2018

\section{Summary}

Barkov S. A., Markeeva A. V., Gavrilenko O. V., Sverdlikova E. A., Lomonosov Moscow State University, Moscow

Poverty and Wealth: the Perception of Russian Internet Users

The article presents the results of the content-analysis of messages in social media about peculiarities of Russian Internet users' attitude of to the problems of poverty and wealth. Communication in Internet suggests a pragmatic orientation. It's not a place for discussions of general socio-economic and socio-political problems. Poverty and wealth are perceived through the prism of consumer behavior, in order to find opportunities to meet the needs of people. In Internet communications, there is an obvious negative assessment of poverty, while attitudes toward wealth and rich, towards social differentiation are represented by more neutral assessments. In the forefront of discussions, there is an opportunity to maintain an acceptable standard of living in difficult economic conditions. People share the recipes of survival in the face of a sharp drop in incomes.

Poverty; wealth; poor; rich; Internet users; social media; network communities; inflation; inequality; consumption; wages; income

\section{References}

Bibkov A. Pochti tret' kompanii zayavila o nachale sokrashcheniya zarplat. (In Russ.). Available at: https://www.rbc.ru/economics/09/04/2015/55267fd09a794 7e81040e8f3 (accessed 18.12.2017).

Ovcharova L. N., Biryukova S. S., Selezneva E. V., Abanokova K. R., Abramova N.V. (2017) Naselenie Rossii v 2017 godu: dokhody, raskhody i sotsial'noe samochuvstvie. Monitoring. Moscow, HSE Publ. 51 p. (In Russ.).

Gorshkov M.K., Krumm R., Tikhonova N.E., Andreev A. L., Anikin V.A., Barash R.E., Byzov L. G., Lezhnina Yu.P., Mareeva S.V., Mchedlova M. M., Petukhov V.V., Tyurina I. O. (2013). O chem mechtayut rossiyane: ideal i real'nost'. Moscow, Ves' mir Publ. 400 p. (In Russ.).

Giddens A., Satton P. (2017). Essential Concepts in Sociology. $2^{\text {nd }}$ Edition. Polity Press. 240 p.

Townsend P. (1979). Poverty in the United Kingdom: A Survey of Household Resources and Standards of Living. Harmondsworth, Penguin. 1216 p.

Townsend P. (2010). Meaning of Poverty. The British Journal of Sociology. No. 61. Pp. 85-102. 